\title{
PROBIOTICS IN GILT NUTRITION ${ }^{1}$
}

\author{
B. Živković, W. Migdal, Č. Radović, M. Fabjan, Olga Kosovac ${ }^{2}$
}

Content: Possibility of use of probiotics in nutrition of pregnant and lactating gilts, as well as suckling piglets. Obtained results showed that gilts fed diet containing probiotics farrowed by 5,7\% more piglets whose body mass at farrowing was by $7,9 \%$ higher, also by $6,8 \%$ more piglets were raised compared to parameters obtained with regular nutrition without additional probiotics. Level of utilization of nutritive substances was also better and value of realized piglets higher by $14 \%$ at farrowing and by $6,8 \%$ at weaning through use of investigated probiotic.

Key words: probiotic, gilts, suckling piglets

\section{Introduction}

Modern and profitable pig production demands high level of knowledge in organization of such production. One of the important factors is high standard of hygiene and ability of piglets to adapt to changes of the environment and especially of nutrition.

One of the ways to solve this problem is adapting of the intestine micro flora in order to realize optimal production results of piglets during lactation. Prevention of the effect of pathogen strains such as Echerichia coli which is most dangerous in pig production is important. It occurs as consequence of reproduction of non pathogenic bacteria produced through action of lactic acid or can be introduced to organism through food.

Considering increasing limitations in regard to use of antibiotics as growth stimulators, more attention is directed towards "alternative" growth stimulators such as probiotics which have positive effect on animal health (Reuter, 2001; Sinovec, 2001).

Since we already obtained positive results and experience with the use of probiotics in nutrition of sows and piglets (Živković et al., 2003), weaned piglets (Živković et al., 2001) and pigs in fattening (Živković et al., 2004), objective of this paper as continuation of the research of same issues was to study the possibility for use of probiotic Digestaze based on strains of Bacilus subtilis, Lactobacillus bufidus and Lactobacillus acidophilus in nutrition of gestating gilts and gilts in lactation, as well as suckling piglets.

\section{Material and methods}

Investigation was carried out on Experimental pig farm of the Institute for Animal Husbandry, Belgrade-Zemun. Trial included total of 12 breeding gilts divided into two groups. According to the technology used on the pig farm, all gilts are inseminated after onset of estrus and after insemination groups were formed and investigation began. Based on standard criteria, origin and initial body mass animals were divided into two groups, 6 gilts in each group, and two nutrition treatments. Nutrition of animals was ad libitum and it consisted of meal mixtures with $16 \%$ of crude proteins during gravidity and nursing period and $22 \%$ of crude proteins during supplementary feeding of piglets. Water was supplied through automatic waterers.

First group of gilts, control, was fed diet of standard composition used on the experimental pig farm (table 1). Second group of gilts was fed diet of same composition but with additional probiotic Digestaza 1000 produced in USA and imported by West Chemie from Belgrade in concentration of $0,004 \%$. Gilts were fed during gravidity with $3,0 \mathrm{~kg} /$ head daily, and during lactation as well as supplementary feeding of piglets were ad libitum.

\footnotetext{
1 Original scientific paper supported by the Ministry of Science and Environmetn Protection, Project no. B.T.N. 5.2.0.7103. B Originalan naučni rad je finansiran od strane Ministarstva za nauku i zaštitu životne sredine Projektom broj: B.T.N. 5.2.0.7103. B. 2 Dr Branislav Živković, scientific counselor, dr Olga Kosovac, research associate, mr Mihal Fabjan, research assistant, Grad. eng. Čedomir Radović, research trainee, Institute for Animal Husbandry, Belgrade-Zemun, Serbia and Montenegro; Prof. Dr Wladyslaw Migdal, associate professor, Akademia Rolnicza, Kraków, Poljska
} 


\begin{tabular}{|c|c|c|}
\hline Group & 1 & 2 \\
\hline \multicolumn{3}{|c|}{ Gestating gilts } \\
\hline Probiotic during gestation period, $\%$ & - & 0,004 \\
\hline Feed/head/day & 3,0 & 3,0 \\
\hline \multicolumn{3}{|c|}{ Lactating gilts } \\
\hline$\%$, Probiotic during lactation & - & 0,004 \\
\hline Feed/head/day & ad libitum & ad libitum \\
\hline \multicolumn{3}{|c|}{ - Suckling piglets } \\
\hline \%-Probiotic during lactation & - & 0,004 \\
\hline Feed/head/day & ad libitum & ad libitum \\
\hline
\end{tabular}

Probiotic Digestaza 1000 was added in mixture both gilts and suckling piglets in concentrations $0.004 \%$ /

As criteria for evaluation of obtained results following parameters were used: consumption of food per sow and feeding day, body mass of sows prior to farrowing, number of farrowed piglets, losses at farrowing, body mass of piglets at farrowing, body mass of piglets at weaning, body mass of sows at weaning, gain of piglets during lactation, level of utilization of nutritive matters at the end of gravidity and economical justification for use of investigated probiotic in mixtures.

Obtained data was processed using traditional methods of statistical processing, variance analysis and data on average values with t-test.

\section{Results and discussion} investigated.

In this trial, the possibility of introduction of probiotic Digestaza 1000 to nutrition of gilts was

Production results

Obtained results (table 2) showed that gilts of the first - control group fed diet without investigated probiotic in mixture, at the end of gravidity in average weighed $155 \mathrm{~kg}$, whereas gilts from the second group, trial group, fed diet containing the investigated probiotic weighed in average $169 \mathrm{~kg}$. At the end of nursing period no significant difference in body masses of gilts could be established. Greater loss of body mass during lactation of $16,63 \%$ against $10,01 \%$, in gilts of trial group on probiotic can be attributed to better utilization of nutritive matters.

Table 2. Performance of gilts and suckling piglets in experiment

\begin{tabular}{|c|c|c|}
\hline Group & 1 & 2 \\
\hline \multicolumn{3}{|c|}{ Gestating gilts } \\
\hline$\%$ - Probiotic during gestation period & - & 0,004 \\
\hline $\mathrm{kg}-$ Body mass of gilts before farrowing & 155,0 & 169,20 \\
\hline \multicolumn{3}{|c|}{ Lactating gilts } \\
\hline Probiotic during lactation & - & 0,004 \\
\hline Average daily feed consumption, $\mathrm{kg}$ & 3,77 & 3,75 \\
\hline Body mass of gilts at weaning, $\mathrm{kg}$ & 139,5 & 140,7 \\
\hline Loss of body mass of gilts during lactation, $\%$ & 10,01 & 16,63 \\
\hline \multicolumn{3}{|c|}{ Suckling piglets } \\
\hline$\%$ - Probiotic during lactation & - & 0,004 \\
\hline Duration of lactation, days & 39 & 38,0 \\
\hline Aver. Number of born piglets/litter & 8,83 & 9,33 \\
\hline Aver. Number of weaned piglets/litter & 7,17 & 7,67 \\
\hline Losses at farrowing, head/litter & 1,66 & 1,67 \\
\hline Aver. body mass of piglets at farrowing & 1,39 & 1,50 \\
\hline kg-Aver.body mass at weaning & 7,04 & 7,01 \\
\hline $\mathrm{g}-$ Av. daily gain of suckling piglets & 146 & 145 \\
\hline
\end{tabular}

Probiotic Digestaza 1000 was added in mixture both gilts and suckling piglets in concentrations $0.004 \%$ / 

established.

During lactation, no significant difference in food consumption between gilts in two groups was

It was established that investigated probiotic in mixture influenced more live born piglets by average 0,50 piglets or $5,66 \%$ in litter compared to control group.

If investigated probiotic is used, body mass of piglets at farrowing increases by $0,11 \mathrm{~kg}$ or $7,91 \%$ compared to piglets from sows fed same mixtures but without additional probiotic.

Losses of piglets during lactation were almost the same in both groups.

At the end of lactation use of probiotics caused more weaned piglets in average by 0,49 piglets or $6,83 \%$ compared to control group. No significant difference in body mass of piglets at weaning between two groups was established.

Level of utilization of nutritive matters

Obtained results regarding this parameter showed that introduction of investigated probiotic into mixture improves the level of utilization of dry and organic matter, crude proteins, fat and fiber in gestating gilts (table 3).

Table 3. Digestibility of nutrients for gestating gilts, \%

\begin{tabular}{|l|c|c|}
\hline Group & 1 & 2 \\
\hline Probiotic during gestation period & - & 0,004 \\
\hline \multicolumn{3}{|c|}{ Nutrients } \\
\hline Dry matter & 76,06 & 78,04 \\
\hline Organic matter & 80,01 & 81,20 \\
\hline Crude protein & 67,51 & 71,85 \\
\hline Ether extracts & 64,59 & 74,76 \\
\hline Crude fiber & 52,30 & 52,53 \\
\hline Nitrogen free extracts & 87,01 & 86,79 \\
\hline
\end{tabular}

Probiotic Digestaza 1000 was added in mixture both gilts and suckling piglets in concentrations $0.004 \%$ /

\section{Economical indicators}

Economical analysis of cost of mixture (table 4) showed that by introduction of probiotic Digestaze 1000 into mixtures increases the cost of diet for gilts during gravidity by $3,28 \%$ compared to mixture without this additive. During nursing period this increase is $3,28 \%$, and during the period of supplementary feeding of piglets it was established that use of probiotics increases the cost of mixture by $1,96 \%$.

In all investigated stages of production within the trial use of probiotic Digestaze 1000 caused increase of cost of nutrition by $2,64 \%$.

Based on value of realized piglets at farrowing it can be concluded that use of probiotic Digestaze 1000 improved piglet production by $14,02 \%$ at farrowing and $6,83 \%$ at the end of nursing period compared to parameters obtained in control group - piglets realized in group of gilts receiving standard mixture without additional probitoic.

Obtained results indicate positive effects of inclusion of probiotic into mixtures for sows (Zani et al., 1998) expressed through better production, (Pupavac et al., 2000; Ignatova, 2004) better fertility and reduced occurrence of MMA in sows (Young et al., 2002; Alexopoulos et al., 2004) as well as reduced occurrence of diarrhea in piglets (Toride et al., 1998). This is attributed to ability of probiotic to survive inside the stomach and small intestines (Reuter, 1997), increase of fatty acids of short chain (Jadamus et al., 2002), alkali protease (Kumprecht et al., 1994), as well as increase of glucose content in small intestines of piglets (Ruchen and Simôes-Nunes, 1995). 
Table 4. Economic analysis of the use probiotic in the experiment

\begin{tabular}{|c|c|c|}
\hline Group & 1 & 2 \\
\hline \multicolumn{3}{|c|}{ Gestating gilts } \\
\hline Probiotic during gestation period & - & 0,004 \\
\hline$\%$ - Price of diets & 100,00 & 103,28 \\
\hline Feed consumption/head/day & 3,0 & 3,0 \\
\hline$\%$ - Feed value/head & 100,00 & 103,28 \\
\hline \multicolumn{3}{|c|}{ Lactating gilts } \\
\hline Probiotic during lactation & - & 0,004 \\
\hline$\%$ - Price of diet & 100,00 & 103,28 \\
\hline Feed consumption/head/day & 3,77 & 3,75 \\
\hline$\%$ - Feed value/head & 100.00 & 101,13 \\
\hline \multicolumn{3}{|c|}{ Suckling piglets } \\
\hline Probiotic during lactation & - & 0,004 \\
\hline$\%$ - Price of diet & 100,00 & 101,96 \\
\hline Feed consumption/head/day & 0,84 & 0,84 \\
\hline$\%$ - Feed value/head & 100,00 & 101,96 \\
\hline \multicolumn{3}{|c|}{ Total costs before farrowing of piglets } \\
\hline$\%$ - Total cost of feed & 100,00 & 102,64 \\
\hline$\%$ - Value of produced piglets. $\%$ & 100,00 & 114,02 \\
\hline \multicolumn{3}{|c|}{ - Total costs before weaning of piglets } \\
\hline$\%$ - Total cost of feed & 100,00 & 102,64 \\
\hline$\%$ - Value of produced piglets. $\%$ & 100,00 & 106,83 \\
\hline
\end{tabular}

\title{
Conclusion
}

In trial carried out on gilts during gestation period and lactation, as well as suckling piglets possibility for use of probiotic Digestaze 1000 in nutrition of mentioned categories of pigs was investigated. Obtained results have shown that:

- There was no difference in consumption of food in gilts during lactation. Nutrition of gilts with mixture containing probitoc caused increase in number of farrowed piglets by $5,7 \%$, higher body mass at farrowing by $7,9 \%$ and more raised piglets by $6,8 \%$ compared to results achieved by animals fed diet without additional probiotic. Level of utilization of nutritive matters was better when probiotic was used. Cost of mixture increased with use of probiotic in average by $2,6 \%$, but value of realized piglets also increased by $14,0 \%$ at weaning and by $6,8 \%$ at weaning.

In general, obtained research results have shown that introduction of investigated probiotic was justified and its use in nutrition of gilts is recommended.

\section{PROBIOTIK U ISHRANI KRMAČA I PRASADI NA SISI}

\author{
B. Živković, W. Migdal, M. Fabjan, Č. Radović
}

$$
\text { Rezime }
$$

U ogledu izvedenom na nazimicama tokom suprasnosti i laktacije kao i prasadima na sisi ispitivana je mogućnost korišćenja probiotika pod nazivom Digestaza 1000 u ishrani ove kategorije svinja . Dobijeni rezultati su pokazali sledece: 
Nije bilo razlike u konzumaciji hrane kod nazimica tokom laktacije. Ishrana nazimica smešom sa probiotikom je dovela do za 5,7\% većeg broja oprašene, sa 7,9\% većom telesnom masom na prašenju, kao i za $6,8 \%$ više odgajene prasadi u poređenju sa pokazateljima ostvarenim na obroku bez dopunskog probiotika. Stepen iskorišćavanja hranljivih materija obroka je bio bolji uz korišćenje probiotika. Cena smeše sa probiotikom se povećava u proseku za $2,6 \%$, ali se povećava vrednost realizovanih prasadi, za $14,0 \%$ na prašenju i za $6,8 \%$ na zalučenju.

U celini dobijeni rezultati istraživanja su pokazali da se uvođenjem ispitivanog probiotika pokazalo opravdanim, te se preporučuje njegovo korišćenje u u ishrani nazimica.

\section{Literature}

1. ALEXOPOUlOS C, GEORGOUlAKIS I. E., TZIVARA E., KRITAS S.K., SLOCHU A., KYRIAKIS S. C. (2004): Field evaluation of the efficacy of a probiotic containing Bacillus lichenformis and Bacillus subtilis spores on the health status and performance of sows and their litters. Journal of Animal Physiology and Animal Nutrition, 88 (11-12), 381-392.

2. IGNATOVA M. (2004): Effect of probiotic ENTEROSAN in lactating sows. II International Conference, Penza. 13-14 October 2004. p. 57-58.

3. JADAMUS A., WAHJEN W., SCHAFTER K., SIMON O. (2002): Influence of the probiotic strain Bacillus cereus var. toyoi on the development of eneterobacterial growth and on selected parameters of bacterial metabolism in digesta samples of piglets. Journal of Animal Physiology and Animal Nutrition, $86,(1 / 2), 42-54$.

4. KARPUT L.M., PUDENKO I. I. (1998): Bacterial preparations in the prevention of dyspepsia in piglets. Nutrition Abstracts and Reviews, 68, 3, 193.

5. KUMPRECHT P., ZOBA; E., ROBOŠOVA E. (1994): Vliv aplikace Bacillus C.I.P. 5832 na vybrané fyziologické ukazatele a užitkovost u selat po odustavu. Živočišná Výroba, 31, 331-340.

6. REUTER G. (1997): Ecology of two strains of probiotics in the intestine of young pigs. Microecology and Therapy, 26, 271-281.

7. RYCHEN G., SIMOES-NUNES C. (1995): Effects of three microbial probiotics on postprandial portoarterial concentration differences of glucose, galactose and amino-nitrogen in young pigs. British Journal of Nutrition, 74 (1), 19-26.

8. SINOVEC Z. (2001): Stimulatori rasta: probiotici kao alternativna mogućnost. Živinarstvo, 36 (10), 195-202.

9. PUPAVAC SNJEŽANA, SINOVEC Z., TRIFUNOVIĆ MIRJANA, HUDINA V., JEREMIĆ D. (2000): Korišćenje antibiotika i probiotika u stimulativne svrhe u ishrani prasadi. XV Savetovanje Agronoma, Veterinara i Tehnologa, Aranđelovac, 6, 471-479.

10. TORIDE Y., SRINONGKOTE S., ONISHI N. (1998): Effect of digested bacterial cell powder (DBCP) on performance of post weaning and suckling piglets. Animal Science and Technology, 69 (1), 8-13.

11. ZANI J. L., CRUZ F.W. da, SANTOS A.F. dos, GILL-TURNES C. (1998): Effect of probiotic CenBiot on the control of diarrhoea and feed efficiency in pigs. Journal of Applied Microbiology, 84 (1), $68-71$.

12. YOUNG Q., BAIDOO S. K., WALKER R. D., MARUBASHI T., arubashi, IMABAYASHI T. (2002): Effect of dietary supplementation of probiotics (Calsporin) on sow and litter performance. Journal of Animal Science, Vol. 80, Supplement 1/3, 390.

13. ŽIVKOVIĆ B., MIGDAL W., FABJAN M., KOVČIN S. (2001): Possibilites for the use of probiotic Paciflor C 10 in the nutrition of weaned piglets. International Scientific Conference "Animal Science in the XXI Century". October, Krakow, Poland, 231-237.

14. ŽIVKOVIĆ B., MIGDAL W., FABJAN M., RADOVIĆ Č. (2003): Probiotic in nutrition of sows and suckling piglets. International Scientific Conference "Science for Practice", September, Kraków, Poland, Roczniki Naukowe Zootechniki, 17/1, Suplement, 309-313.

15. ŽIVKOVIĆ B., MIGDAL W., FABJAN M., KOVČIN S., RADOVIĆ Č., KOSOVAC OLGA, TODOROVIĆ MIRJANA, JOKIĆ Ž. (2004): Nutritivna vrednost probiotika u ishrani svinja u tovu. Biotehnologija u stočarstvu, Vol. 20, N ${ }^{\mathrm{o}} 1-2,51-58$. 